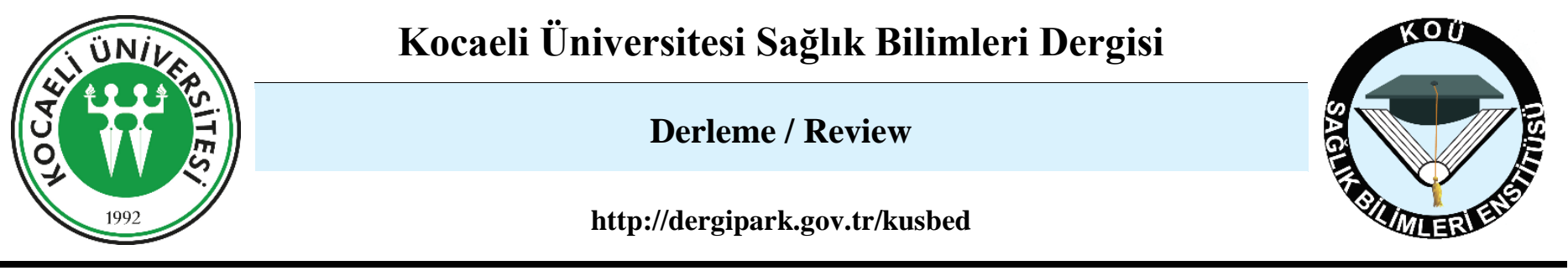

\title{
ABDOMINAL CERRAHIDE ANESTEZI
}

ANESTHESIA FOR ABDOMINAL SURGERY

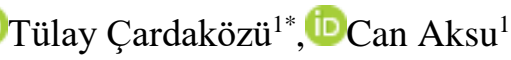

${ }^{1}$ Kocaeli Üniversitesi, Tıp Fakültesi, Anesteziyoloji ve Reanimasyon Anabilim Dalı, Kocaeli, Türkiye

ORCID iD: Tülay Çardaközü: 0000-0002-4936-8020; Can Aksu: 0000-0002-4389-4257

*Sorumlu Yazar / Corresponding Author: Tülay Çardaközü, e-posta / e-mail: tulayhosten@ hotmail.com

$\ddot{O} z$

Günümüzde teknoloji, cerrahi ve anestezideki gelişmeler ameliyat öncesi ve ameliyat sonrası hasta bakımında ilerlemelere neden olmuş ve artık cerrahi en son başvurulan tedavi yöntemi olmaktan çıkmıştır. Abdominal cerrahiye yönelik girişimler mide, safra, karaciğer, dalak, pankreas, ince bağırsak ve kalın bağırsaktaki hastalıkları kapsamakta ve ileri yaş grubunda cerrahi gerektiğinde komorbid hastalıkları nedeniyle ilave sorunları da beraberinde getirmektedir. Acil olduğu durumlarda bu sorunlar daha da artmaktadır. Bu derlemede abdominal cerrahi yapılacak hastalarda perioperatif anestezi yönetimini anlatmayı amaçladık.

Anahtar Kelimeler: Anestezi, batın, cerrahi

\begin{abstract}
Today advances in technology, surgery and anesthesia have led to advances in preoperative and postoperative patient care and surgery is no longer the last resort. Procedures for abdominal surgery is included stomach, bile, liver, spleen, pancreas, small intestine, and large intestine surgeries, and because these surgeries are particularly concerned with advanced age group, they also cause additional problems due to comorbid diseases. In emergency cases, these problems are increasing. In this review we aimed to describe the perioperative anesthesia management in patients to undergo abdominal surgery.
\end{abstract}

Keywords: Anesthesia, abdomen, surgery 


\section{Giriş}

Abdominal cerrahiye yönelik girișimler, mide, safra kesesi ve safra yolları, karaciğer, dalak, pankreas ile ince ve kalın bağırsakta ortaya çıkan hastalıkları kapsamakta ve bu cerrahiler özellikle ileri yaş grubunu ilgilendirdiğinde komorbid hastalıkları nedeniyle ilave sorunları da beraberinde getirmektedir. Abdominal cerrahinin acil olduğu durumlarda bu sorunlar daha da artmaktadır. Abdominal cerrahi planlanan hastalarda sorunların önceden bilinmesi, preoperatif dönemden itibaren hasta hazırlığı açısından önemlidir. ${ }^{1}$

\section{Abdominal Cerrahiye İlişkin Sorunlar}

1- Pulmoner komplikasyonlar: Üst abdominal cerrahide alt abdominal cerrahiye göre daha fazladır, sıklı̆̆ $\% 12-88$ oranında değişir. ${ }^{2}$

2- Postoperatif ağrı: İyi düzenlenmemiş postoperatif analjezi solunumla ilgili problemleri daha da arttırır.

3- Hipotermi: Genel anestezinin (GA) etkilerine ilave olarak evaporasyon, kondüksiyon ve radyasyon yoluyla oluşan hipotermi; organ perfüzyonunun azalmasına ve metabolik asidoza neden olur.

4- Malnütrisyon, mekanik bağırsak temizliği, laksatifler, ileostomiler, kusma ve diyare; siv1 ve elektrolit bozukluklarına neden olabilir.

5- Kolon, pankreas ve mide kanserinde daha fazla olmak üzere hiperkoagülabilite riski vardır.

6- Kemoterapötik ajanların anemi, renal, hepatik, pulmoner toksisite ve kardiyomiyopati gibi sistemik yan etkileri göz ardi edilmemelidir.

7- Kanser tedavisinde postoperatif ağrı için opioid ihtiyacı artabilir.

8- Hastalar, elektif ya da günübirlik hastadan çok acil hastaya kadar çeşitlilik gösterebilir; bu nedenle anestezi teknikleri de bu çeşitliliği yansıtmak zorundadır.

9- Acil durumlar hipovolemik şok ve endotoksemi ile komplike olabilir ve sepsise dönüşebilir.

Anestezi yönetimi, iyi bir preoperatif değerlendirme ile başlamalıdır.

\section{Preoperatif Değerlendirme}

Amaç hastanın fiziksel durumunu tespit etmek, komorbiditesi olan hastalarda risk durumunu belirlemek ve risk azaltıcı stratejilerle hastayı cerrahi için optimum hale getirmektir. Bunun için çeşitli skorlama sistemleri geliştirilmiş olmakla birlikte en yaygın kullanılanı Amerikan Anestezistler Birliği (American Society of Anesthesiologists) (ASA) skorlama sistemidir (Çizelge 1). ${ }^{3}$ ASA skorlama sistemi, cerrahinin ve anestezinin türüne bakmaksızın hastanın medikal durumunu bildiren bir skorlama sistemidir. ASA skoru yükseldikçe mortalite oranı da artmaktadır. ${ }^{3}$ ASA skorlama sisteminin anestezik yaklaşımın ve özellikle monitorizasyon yöntemlerinin belirlenmesinde oldukça yararlı olduğu kabul edilmektedir.
Çizelge 1. American Society of Anesthesiologists (ASA) siniflamas ${ }^{3}$

\begin{tabular}{|c|c|c|}
\hline $\begin{array}{l}\text { ASA } \\
\text { sinıflaması }\end{array}$ & & \\
\hline ASA I & $\begin{array}{l}\text { Normal, sistemik bozukluğa } \\
\text { neden olmayan cerrahi patoloji } \\
\text { dışında bir hastalık veya sistemik } \\
\text { sorunu olmayan sağlıklı kişi }\end{array}$ & Sağlıklı, sigara içmeyen kişi \\
\hline ASA II & $\begin{array}{l}\text { Cerrahi girişim gerektiren nedene } \\
\text { veya başka bir hastalığa bağlı } \\
\text { hafif bir sistemik bozukluğu olan } \\
\text { kişi. }\end{array}$ & $\begin{array}{l}\text { Sigara öyküsü, obezite, } \\
\text { kontrollü diyabet, kontrollü } \\
\text { hipertansiyon, hafif akciğer } \\
\text { hastalığı olan kişiler }\end{array}$ \\
\hline ASA III & $\begin{array}{l}\text { Aktivitesini sınırlayan, ancak } \\
\text { güçsüz bırakmayan hastalığı olan } \\
\text { kişi. }\end{array}$ & $\begin{array}{l}\text { Latent kalp yetmezliği, } \\
\text { geçirilmiş miyokard infarktüsü, } \\
\text { ejeksiyon fraksiyonu \% } 40 \text { 'ın } \\
\text { altındaki hastalar, ileri diyabet, } \\
\text { sınırlı akciğer fonksiyonu }\end{array}$ \\
\hline ASA IV & $\begin{array}{l}\text { Gücünü tamamen yitirmesine } \\
\text { neden olup hayatına sürekli bir } \\
\text { tehdit oluşturan bir hastalığ olan } \\
\text { kişi. }\end{array}$ & $\begin{array}{l}\text { Şok, dekompanse kalp veya } \\
\text { solunum sistemi hastalığı, } \\
\text { ejeksiyon fraksiyonu \% } \% 25 \text { 'in } \\
\text { altında olan kişiler, böbrek, } \\
\text { karaciğer yetmezliği olması }\end{array}$ \\
\hline ASA V & $\begin{array}{l}\text { Ameliyat olsa da olmasa da } 24 \\
\text { saatten fazla yaşaması } \\
\text { beklenmeyen, ölüm halindeki } \\
\text { kişi }\end{array}$ & $\begin{array}{l}\text { Rüptüre abdominal ve/veya } \\
\text { toraks anevrizması, intrakranial } \\
\text { kanama, kardiyak patoloji } \\
\text { sebebiyle iskemik bağırsak } \\
\text { hastalıkları }\end{array}$ \\
\hline ASA VI & $\begin{array}{l}\text { Organ alınmaya uygun, beyin } \\
\text { ölümü gelişmiş hastalar } \\
\text { girmektedir. }\end{array}$ & \\
\hline
\end{tabular}

ASA: American Society of Anesthesiologists

Acil cerrahi girişim gerektiğinde hastanın sınıflama numarasından sonra "E" harfi eklenmektedir.

Bunun dışında hastanın var olan komorbid hastalıkların ciddiyetine göre de ASA sınıflaması yapılmaktadır (Çizelge 2-5).

Çizelge 2. Kardiyovasküler hastalığı olanlarda ASA sınıflaması ${ }^{3}$

\begin{tabular}{|c|c|c|c|}
\hline & ASA II & ASA III & ASA IV \\
\hline Angina & $\begin{array}{l}\text { Ayda 2-3 kez dil } \\
\text { altı nitrat alan } \\
\text { hasta }\end{array}$ & $\begin{array}{l}\text { Haftada } 2-3 \mathrm{kez} \text { dil } \\
\text { altı nitrat alan hasta, } \\
\text { anstabil angina }\end{array}$ & $\begin{array}{l}\text { Yaşamı tehdit eden } \\
\text { KVS hastalıkları: } \\
\text { Dekompanse kalp }\end{array}$ \\
\hline Egzersiz kapasitesi & Rahat aktivite & $\begin{array}{l}\text { Sinırlı aktivite } \\
\text { (merdiven çıkma } \\
\text { koşma sınırlı) }\end{array}$ & $\begin{array}{l}\text { yetmezliği, akut veya } \\
\text { yeni miyokard } \\
\text { enfarktüsü, şiddetli }\end{array}$ \\
\hline Hipertansiyon & $\begin{array}{l}\text { Tek ilaç ile } \\
\text { kontrolde }\end{array}$ & $\begin{array}{l}\text { Kontrol } \\
\text { edilememiş, } \\
\text { multipl ilaç } \\
\text { kullanan }\end{array}$ & $\begin{array}{l}\text { kapak hastalığı, } \\
\text { ventriküler aritmi, } \\
\text { ventrikül hızı kontrol } \\
\text { altına alınamayan }\end{array}$ \\
\hline $\begin{array}{l}\text { Birden } \\
\text { fazla KVS hastalığ } 1\end{array}$ & $\begin{array}{l}2 \text { farklı KVS } \\
\text { hastalığı, } \\
\text { ikisi de kontrol } \\
\text { altında, } \\
\text { komplikasyon } \\
\text { yok }\end{array}$ & 2 'den fazla & $\begin{array}{l}\text { supraventriküler } \\
\text { taşikardiler, } \\
\text { tam AV blok }\end{array}$ \\
\hline $\begin{array}{l}\text { Beraberinde } \\
\text { Diyabet }\end{array}$ & $\begin{array}{l}\text { Kontrolde } \\
\text { komplikasyon } \\
\text { yok } \\
\text { Kreatinin } \square 2\end{array}$ & $\begin{array}{l}\text { Kontrol edilememiş, } \\
\text { Komplikasyon var } \\
\text { Kreatinin } \square 2\end{array}$ & \\
\hline
\end{tabular}

KVS: kardiyovasküler sistem, AV: atriyoventriküler 
Çizelge 3. Solunum sistemi hastalıklarında ASA sınıflamas ${ }^{3}$

\begin{tabular}{|c|c|c|c|}
\hline & ASA II & ASA III & ASA IV \\
\hline KOAH & $\begin{array}{l}\text { Öksürük var, } \\
\text { inhaler ile } \\
\text { kontrol } \\
\text { edilebilen } \\
\text { hışıltı, ara sıra } \\
\text { akut } \\
\text { enfeksiyonu } \\
\text { olan hasta }\end{array}$ & $\begin{array}{l}\text { Öksürük var, } \\
\text { inhaler ile kontrol } \\
\text { edilebilen hışıltı, } \\
\text { ara sira akut } \\
\text { enfeksiyonu olan } \\
\text { hasta }\end{array}$ & $\begin{array}{l}\text { Yaşamı tehdit eden } \\
\text { solunumsal } \\
\text { hastalıklar: İstiraha } \\
\text { halinde ağır dispnesi } \\
\text { ve siyanozu olan } \\
\text { hastalar, ARDS, } \\
\text { şiddetli göğüs } \\
\text { travması, }\end{array}$ \\
\hline Astım & $\begin{array}{l}\text { İnhaler ile } \\
\text { kontrolde, } \\
\text { yaşamı } \\
\text { kıstlamıyor 1-2 } \\
\text { kat merdiven } \\
\text { çıkabilir }\end{array}$ & $\begin{array}{l}\text { Yüksek doz } \\
\text { inhaler ve streoid } \\
\text { aliyor, ara sıra } \\
\text { hastanede yatarak } \\
\text { tedavi oluyor }\end{array}$ & $\begin{array}{l}\text { pnömotoraks, } \\
\text { pnömoni, kronik } \\
\text { solunumsal } \\
\text { hastalıklarda FEV'in } \\
\% 50 \text { altında, parsiye } \\
\text { arteriyel oksijen }\end{array}$ \\
\hline $\begin{array}{l}\text { Fonksiyonel } \\
\text { kapasite }\end{array}$ & $\begin{array}{l}1-2 \text { kat } \\
\text { merdiven } \\
\text { c1kabilir }\end{array}$ & $\begin{array}{l}\text { 1-2 kat merdiven } \\
\text { çıkamaz }\end{array}$ & $\begin{array}{l}\text { basincinın } 60 \\
\text { mmHg'nın } \\
\text { altında ve parsiyel }\end{array}$ \\
\hline $\begin{array}{l}\text { Beraberinde } \\
\text { obezite }\end{array}$ & Hafif obezite & $\begin{array}{l}\text { Aşırı veya morbid } \\
\text { obezite }\end{array}$ & $\begin{array}{l}\text { arteriyel } \\
\text { karbondioksit }\end{array}$ \\
\hline Sigara içimi & $\begin{array}{l}\text { Günde } 1 \\
\text { paketten az }\end{array}$ & $\begin{array}{l}\text { Uzun yillar günde } \\
1 \text { paketten fazla }\end{array}$ & $\begin{array}{l}\text { basıncının } 45 \mathrm{mmHg} \\
\text { üzerinde olması }\end{array}$ \\
\hline $\begin{array}{l}\text { Spinal veya } \\
\text { torasik } \\
\text { deformite }\end{array}$ & Yok & Var & \\
\hline
\end{tabular}

ARDS: Akut respiratuvar distres sendromu, FEV: zorlu ekspiratuar volüm, KOAH: kronik obstrüktif akciğer hastalığ

Solunum fonksiyon testleri tanı ve tedaviye yanıtı belirlemede önemlidir; bu testlerin risk belirlemede yeri yoktur. Pulmoner komplikasyonlar için risk faktörleri sigara, yaş $>70$, ASA $>2$, cerrahi süresi $>2$ saat, vücut kitle indeksi $>30$, albümin $<3 \mathrm{~g} / \mathrm{dL}$ ve KOAH varlığıdır. Astım iyi kontrol edilmişse komplikasyon riski azdır.

Çizelge 4. Böbrek hastalığı olanlarda ASA sınıflaması ${ }^{3}$

\begin{tabular}{l|lll}
\hline & ASA II & ASA III & ASA IV \\
\hline Kreatinin & $<2 \mathrm{mg} / \mathrm{dL}$ & $<2 \mathrm{mg} / \mathrm{dL}$ & $\begin{array}{l}\text { Yaşamı tehdit eden } \\
\text { renal hastalıklar: } \\
\text { Akut böbrek } \\
\text { yetmezliği, ağır } \\
\text { elektrolit } \\
\text { hipotansiyon } \\
\text { dengesizliği, } \\
\text { perikard, plevra } \\
\text { efüzyonuna bağlı } \\
\text { kardiyopulmoner } \\
\text { yetmezlik, pulmoner }\end{array}$ \\
$\begin{array}{llll}\text { Diyabet } \\
\text { enfeksiyon gelişmiş }\end{array}$ \\
$\begin{array}{l}\text { Plevra- } \\
\text { perikard } \\
\text { efüzyonu }\end{array}$ & $\begin{array}{l}\text { Kontrol altında } \\
\text { kontrol altında }\end{array}$ & $\begin{array}{l}\text { Kontrol altında } \\
\text { değil }\end{array}$ & $\begin{array}{l}\text { Kan şekeri kontrol böbrek } \\
\text { altında değil } \\
\text { Yastaları }\end{array}$ \\
\hline
\end{tabular}

KVS: kardiyovaskuler sistem, AV: atriyoventriküler

Çizelge 5. Karaciğer hastalığı olanlarda ASA sınıflamas $1^{3}$

\begin{tabular}{l|lll}
\hline & ASA II & ASA III & ASA IV \\
\hline $\begin{array}{l}\text { Serum bilirubin } \\
(\mathrm{mg} / \mathrm{dL})\end{array}$ & $<1,5$ & $1,5-2,4$ & $>2,4$ \\
$\begin{array}{l}\text { Serum albümin }(\mathrm{g} / \mathrm{dL}) \\
\text { Protrombin zamanı } \\
(\mathrm{s})\end{array}$ & $>3,5$ & $2,8-3,5$ & $<2,8$ \\
Ansefalopati & 1,4 & $4-6$ & $>6$ \\
Asit & Yok & Orta & İlerlemiş \\
\hline
\end{tabular}

KVS: kardiyovaskuler sistem, AV: atriyoventriküler blok

Ciddi karaciğer hastalığ morbidite nedenidir. Child-Turcotte-Pugh klasifikasyonu ile tahmin edilebilir. İntraabdominal cerrahide yaklaşık mortalite oranı Child Pugh A grubu hastalarda \%10, Child Pugh B ve C olan olgularda ise sırasıyla $\% 30$ ve $\% 82$ olarak bildirilmiştir. ${ }^{4}$ Hastanın geçireceği cerrahinin türüne bakıldığında, abdominal cerrahinin orta ve yüksek riskli grupta olduğunu görmekteyiz (Çizelge 6).
Çizelge 6. Cerrahi girișim tipine göre cerrahi risk tahmini ${ }^{3}$

\begin{tabular}{l|ll}
\hline Düşük risk (<\%1) & Orta risk (\%1-5) & Yüksek risk (>\%5) \\
\hline Yüzeysel cerrahi & İntraperitoneal splenektomi, & Aortik ve büyük \\
Meme & hiatal herni onarımı, & damar cerrahisi \\
Diş & kolesistektomi & Açık alt ekstremite \\
Endokrin (tiroid) & Semptomatik karotis cerrahisi & revaskülarizasyon \\
Göz & Periferik arteriyel anjiyoplasti & veya \\
Rekonstrüktif Asemptomatik & Endovasküler anevrizma & Duodenopankreatik \\
karotis & onarımı & cerrahi \\
Minör jinekolojik & Baş ve boyun cerrahisi & Karaciğer \\
Minör ortopedik & Major nörolojik veya & rezeksiyonu ve safra \\
Minör ürolojik (prostatın & ortopedik & yolları cerrahisi \\
transüretral rezeksiyonu) & Major ürolojik ve jinekolojik & Özofajektomi \\
& Böbrek nakli & Perfore bağırsak \\
& Major olmayan intratorasik & onarımı \\
& cerrahi & Adrenal rezeksiyon \\
& & Total sistektomi \\
& & Akciğer rezeksiyonu \\
& & Akciğer ve karaciğer \\
& & nakli \\
\hline
\end{tabular}

\section{Gastrointestinal Sistemin Fonksiyonel Anatomisi ve Fizyolojisi}

Gastrointestinal sistemin (GİS) fonksiyonel anatomi ve fizyolojisinin bilinmesi, hem cerrahi hem de anesteziye bağlı istenmeyen sistemik ve lokal etkilerin önlenmesi açısından önemlidir. Karın boşluğuna rektus, internal ve eksternal oblik ve transvers kasların oluşturduğu karın ön duvarından girilir. Karın iç duvarını kaplayan parietal periton afferent sinir lifleri içerirken, visseral peritonda bu lifler bulunmaz. Visseral periton elleme ve kesilmeye duyarsız, gerilme ve çekilmeye duyarlıdır. Visseral ağrı lokalize edilemez; bulantı, terleme, taşikardi gibi otonom belirtilerle birliktedir. ${ }^{1}$

\section{Genel Yapı}

GISS motilitesi enterik ve ekstrensek sinir sistemi ile inerve olan düz ve sirküler kaslarca sağlanır. Enterik sinir sistemi gastrointestinal hareketlerden sorumlu miyenterik ve submukozal ağdan oluşur. Özofagusta başlar ve anüse kadar devam eder. Ekstrensek sinir sistemi sempatik ve parasempatik sistemi (PS) içerir. Sempatik sinir sistemi sekresyon, motilite ve kan akımını azaltır, sfinkterleri kasar. Sempatik miyelinsiz C lifleri sindirim sisteminden ağrı duyusunu merkezi sinir sistemine taşır. ${ }^{5}$

\section{Splanknik Dolaşım}

Gastrointestinal sistemi (GİS) besleyen kan akımı superior mezenterik, inferior mezenterik ve çölyak trunkus tarafindan sağlanır ve splanknik dolaşım olarak adlandırılır. Kardiyak debinin istirahatte \%20-25'ini alır. Karaciğer portal venden $\% 75$, hepatik arterden \%25 oranında kanlanır. Portal ven, inferior ve superior mezenterik venlerin birleşiminden oluşur. GİS'in besinden zengin kanını karaciğere götürür. Portal ven ve arteria hepatika propria karaciğere girdikten sonra çok sayıda dala bölünür ve hepatik venler yoluyla karaciğeri terk eder. Hipotansiyon eşlik etmediği sürece rejyonal anestezinin karaciğer kan akımına etkisi minimaldir; GA ise karaciğer kan akımını \%20-30 oranında homojen olarak azaltır. Splanknik dolaşımın otoregülasyonu; intrensek ve ekstrensek faktörler tarafından sağlanır. Splanknik dolaşımı etkileyen faktörler Çizelge 7'de belirtilmiştir. 
Çizelge 7. Splanknik dolaşımı etkileyen vazoaktif mediyatörler ${ }^{6}$

\begin{tabular}{l|l}
\hline Vazodilatörler & Vazokonstriktörler \\
\hline Parasempatik tonus & Sempatik tonus \\
$\mathrm{PO}_{2}$ azalmas1 & $\mathrm{PO}_{2}$ artmas1 \\
$\mathrm{PCO}_{2}$ artmas1 & $\mathrm{PCO}_{2}$ azalmas1, \\
$\mathrm{H}^{+}$azalmas1 & $\mathrm{H}^{+}$artmas1, \\
Asetilkolin & Vazopresin, \\
Bradikinin & Anjiyotensin II \\
Adenozin & Prostoglandinler \\
Gastrin & Peptid YY \\
Sekretin & Nöropeptid Y \\
Kolesistokinin & \\
Vazointestinal peptid & \\
Substans-P & \\
Prostoglandinler & \\
Gastrointestinal peptid & \\
Lökotrienler & \\
Nitrik oksit & \\
Dopamin & \\
\hline
\end{tabular}

Splanknik dolaşım bozukluğu, çoklu organ yetmezliği sendromuna katkıda bulunabilir. Çok büyük tidal hacimlerin, yüksek düzeyde ekspiryum sonu pozitif havayolu basıncının ve yüksek inspiratuar basınçların splanknik perfüzyonu azalttığ1 gösterilmiştir. Torakal epidural analjeziye (TEA) bağlı hipotansiyon ile splanknik kan akımı arasındaki ilişki kolorektal cerrahide çalışılmış ve TEA'nın hipotansiyona bağlı doku perfüzyon bozukluğuna yol açarak anastomoz kaçağı riskini artırmadığı ve aslında yararlı olabileceği belirtilmiştir. $^{7}$

\section{Abdominal Cerrahide Anestezi Teknikleri}

1. GA, genellikle tercih edilen yöntemdir.

2. Rejyonal anestezi teknikleri spinal, epidural, kaudal ve sinir bloklarını içerir. Alt abdomen cerrahisi için T4-6 düzeyinde bir duysal blok yaratacak düzeyde olmalıdır. Üst abdominal cerrahi ise T2-4 duyu bloğu gerektirir ve tek başına tolere edilemez. Yüksek seviyede torasik blok, interkostal kasları bloke eder ve derin soluk almayı engeller; hasta nefes alamamaktan şikayet eder. Yüksek sempatik blokajın hemodinamik yan etkileri de unutulmamalıdır. Ayrıca sempatik blokaja bağlı bağırsak kontraksiyonu da cerrahi memnuniyeti azaltır. Spinal anestezi etki süresiyle uyumlu olarak özellikle alt batın cerrahisi geçirecek açık ve laparoskopik vakalarda uygulanabilir.

3. Kombine teknik GA'ya ilave epidural anestezi anestezik ihtiyacını azaltır. Özellikle üst abdominal cerrahide postoperatif pulmoner fonksiyonlar üzerine olumlu etkisi gösterilmiştir.

\section{Anestezi Yönetimi}

Standart monitörizasyona ilave olarak hastanın komorbid durumuna ve cerrahinin büyüklüğüne göre, invazif arteriyel kateter ve santral venöz basınç (SVB) kateteri, sıcaklık ve idrar monitörizasyonu, minimal invazif hemodinamik monitörizasyon (atım hacmi değişimi, AHD), nabız basıncı değişimi (NBD), sistolik basınç değişimi (SBD) uygulanabilir.

Kusma ve aspirasyon riski olan hastalarda hızlı seri indüksiyon ve entübasyon düşünülmelidir. Kusma ve aspirasyon riski yüksek hasta grubunda travması, bağırsak tıkanıklığı veya ileusu, semptomatik hiatal hernisi, ikinci veya üçüncü trimester gebeliği veya asiti olan ve acil cerrahi girişim gerektiren hastalar yer almaktadır.

\section{Anestezi İdamesi}

GA (inhalasyon anestezikleri veya intravenöz anestezikler ile) tek başına veya TEA ile kombine

edilerek uygulanabilir. Yeterli kas gevşekliği sağlanmalıdır.
$\% 60 \mathrm{~N}_{2} 0$ kullanıldığında bağırsak içi gaz volümü 10 dakikada iki katına çıkar; bu nedenle ileusu ve obstrüksiyonu olan hastalarda kullanılması önerilmemektedir. Travma ve bağırsak obstrüksiyonu olanlarda preoperatif olarak yerleştirilen nazogastrik (NG) sonda mideyi tamamen boşaltmayabilir. NG ile anestezi indüksiyonundan önce aspirasyon yapılmalı ve mide, serbest drenaja birakılmalıdır. $\mathrm{Bu}$ esnada krikoid bası sondaya bağlı reflüyü önleyebilir. NG ve orogastrik (OG) sondalar intraoperatif dönemde yerleştirilirken aşırı zorlamalardan kaçınmak gerekir. ${ }^{8}$

\section{Majör Abdominal Cerrahiler Özofajektomi}

Üst özofagus sfinkteri özofagus başlangıcında, farinksin hemen altındadır. İnspirasyon sırasında aerofajiyi önler ve gastroözofageal reflüye (GÖR) karşı üst özofagusta bariyer oluşturur. Alt özofagus (kardiya) sfinkteri, özofagusun diyafragmayı geçtiği yerde bulunur. Yutma dışında kapalıdır ve mide sıvısının özofagusa geçişini engeller. İstemsiz çalışır. Anestezi uygulamasında kullanılan ilaçların alt özofageal sfinkter basincına etkilerinin bilinmesi, aspirasyon ve regürjitasyon açısından önemlidir (Çizelge 8).

Çizelge 8. Anestezi uygulamasında kullanılan ilaçların alt özofageal sfinkter basıncina etkileri ${ }^{9}$

\begin{tabular}{l|l|l}
\hline Artıran & Azaltan & Etkisiz \\
Metoklopramid & İnhalasyon anestezikleri & H2 reseptör \\
Asetilkolin & Opioidler & antanistleri \\
Süksinilkolin & Antikolinerjikler-atropin & Nondepolarizan kas \\
gevşeticiler \\
Antikolinesterazlar & Tiyopental & Propranolol \\
Kolinerjikler & Propofol & \\
Antiasitler & Beta-agonistler & \\
Gastrin & Ganglion blokerleri & \\
Serotonin & Trisiklik antidepresanlar & \\
Histamin & Sekretin & \\
Metoprolol & Glukagon & \\
Alfa-2 adrenerjikler & Krikoid basisi & \\
& Obezite & \\
& Gebelik & \\
& Hiatal herni & \\
\hline
\end{tabular}

\section{Özofajektomi Endikasyonları;}

- Özofagusun alt veya orta $1 / 3$ segmentinde lokalize malin hastalıklar,

- Barret özefagus,

- Dilatasyona yanit alınamayan motilite hastalıkları (akalazya)

\section{Cerrahi Yaklaşım}

1-Torakoabdominal

2-Transhiatal (abdomen ve boyun insizyonları)

3-Torakal

Özofajektomi belirgin bir sistemik inflamatuar yanıt sendromu ortaya çıkarır. Yüksek riskli bir cerrahidir. Postoperatif olguların \%25'inde solunum yolu, \% 12'sinde kardiyovasküler ve \%16'sında anastomoz kaçağı komplikasyonları vardır.

\section{Preoperatif Değerlendirme}

Alkol, sigara, GÖR hastalığı ve obezite özofagus kanseri için risk faktörlerindendir. Preoperatif değerlendirmede bu risk faktörleri göz ardı edilmemelidir. Malignite cerrahisine alınan hastalar sıklıkla neoadjuvan tedavi kullanırlar. Kronik alkol kullanımı veya neoadjuvan alanlarda kardiyomiyopati (daunorubisin ve doksorubisin) beklenebilir. Bleomisin akciğer toksisitesine, GÖR ise akciğer enfeksiyonlarına neden olabilir. Malnütrisyon, anemi, elektrolit bozuklukları sıktır. 


\section{Anestezi Yönetimi}

Zor havayolu olasılı̆̆1 değerlendirilmelidir. Postoperatif mekanik ventilasyon desteği gerekecek hastalarda tek akciğer ventilasyonu için bronşiyal bloker tercih edilebilir. Pozisyon verildiğinde basınç noktaları yumuşak pedlerle desteklenmelidir. Torasik yaklaşımda kalbe geçici bası, aritmi ve hipotansiyona neden olabilir. Ekstübasyon, cerrahinin süresine ve hastanın kardiyopulmoner durumuna bağlıdır. ${ }^{10-12}$

\section{Pankreatektomi}

\section{Endikasyonlar:}

Nekrotizan pankreatit

Kronik pankreatit

Travma

Tümör

Pankreas kanserlerinin \%95'i duktal adenokarsinomdur ve genellikle pankreas başındadır. Whipple operasyonu, pankreas başı lezyonları için pankreatikoduodenektomiyi içerir.

\section{Pankreas Cerrahisinde Preoperatif Değerlendirme}

Cerrahinin etiyolojisine göre organ ve sistemler farklı şekilde etkilenir. Akut pankreatitli hastalar hipovolemik olup agresif sıv1 tedavisi gerektirebilirler. Elektrolit dengesizliği (hipokloremik metabolik alkaloz, hipokalsemi, hipomagnezemi) ve hiperglisemi görülebilir. Plevral efüzyon, atelektazi ve ARDS gelişebilir. Sarılık, ileus, intestinal obstrüksiyon olabilir. Pankreas tümörleri, diabetes mellitus, hormon salgılayan tümörler multipl endokrin neoplaziler ile birlikte görülebilir. İnsülinoma en sık rastlananıdır ve hipoglisemiyle birliktedir. Renal yetmezlik göz ardı edilmemelidir. Hemokonsantrasyona bağlı yanlış yüksek hematokrit değerleri, koagülopati ve yaygın intravasküler koagülopati gözlenebilir.

\section{Anestezi Yönetimi}

Dehidrate hastalarda anestezi indüksiyonunda önce volüm replasmanı gerekebilir. Pozisyon verildiğinde basınç noktaları yumuşak pedlerle desteklenmelidir. Postoperatif ekstübasyon ya da yoğun bakım ünitesinde takip kararı, cerrahinin süresine ve hastanın kardiyopulmoner rezervine bağlıdır. ${ }^{11,12}$

\section{Karaciğer Rezeksiyonu}

Karaciğer ya da diğer organların sekonder kaynaklı tümörleri nedeniyle gerçekleştirilir. Bazı hastalarda karaciğer fonksiyonları tamamen normal olabilir. Sağlam karaciğer, rezeksiyondan sonra, üç ayda tam rejenerasyon göstermesine rağmen, orijinal boyutuna altı ayda ulaşır. Sirotik karaciğerde rejenerasyon kisitlidir.

\section{Preoperatif Değerlendirme}

Hepatik sirozu olanlarda ve olmayanlarda farkl11ıklar içerir.

Sirozu olmayanda, standart preoperatif fizik muayene, hastanın diğer yandaş hastalıklarını da içeren laboratuvar ve görüntüleme yöntemleri ve gerekli ise konsültasyonlar istenir. Hepatik sirozu olan hastalar, karaciğer yetmezliğine karşı son derece hassastırlar; ancak kronik karaciğer hastalığ anestezi verilmesine mutlak bir kontrendikasyon teşkil etmez. Karaciğer rezeksiyonundan sonra hepatik rejenerasyon düzeyleri önemli ölçüde düşer ve Child-Pugh sınıfı B veya $C$ bir hastayı majör rezeksiyondan çıkartabilir. Uzun süreli cerrahi ve altta yatan metastatik kanser nedeniyle karaciğer rezeksiyonu uygulanan hastalarda venöz tromboembolizm riski artmıştır. Hiperbilürinemi, perioperatif böbrek yetmezliği ile ilişkisi nedeniyle önemlidir. Karaciğer rezeksiyonunda santral nöroaksiyel blokajda koagülopati göz ardı edilmemelidir. Preoperatif karaciğer ile ilişkili koagülopatiyi düzeltmek için $\mathrm{K}$ vitamini, taze donmuş plazma veya kriyopresipitat gerekebilir. Bu hastalarda trombositopeni ve trombosit fonksiyon bozukluğu ihtimali de göz önünde bulundurulmalıdır. Asit gelişimi, sirozda kötü prognoz işaretidir ve perioperatif solunum mekanizmasını olumsuz yönde etkileyebilir. Diürez ve parasentez dahil olmak üzere medikal tedavi ile birlikte, ciddi intravasküler hipovolemi riski vardır. Ameliyat öncesi bu durumu düzeltmek için girişimlerde bulunulmalıdır. Perioperatif sıvı kısıtlaması postoperatif asit gelişimini engellemeyebilir. Ansefalopatinin kesin ve etkili tedavisi sağlanana kadar elektif hepatik cerrahi ertelenmelidir. Geniş karaciğer rezeksiyonlarını tolere edemeyen hastalarda alternatif olarak radyofrekans ablazyonu, kemoembolizasyon, kriyoablasyon ve yakın zamanda uygulanan seçici internal radyoterapi teknikleri uygulanabilir.

\section{Intraoperatif Yönetim}

İntraoperatif aşırı kan kaybı, erken ve uzun dönem olumsuz sonuçlarla ilişkilidir. Karaciğer parankiminin cerrahi transseksiyonu yüksek kan kaybı riski taşımaktadır. Kanama riskini azaltmak için çeşitli cerrahi teknikler kullanılabilir. Karaciğer rezeksiyonu sırasında anestezi teknikleri, optimum sıvı yönetimi yoluyla kan kaybını en aza indirmek ve bu sayede gereksiz kan transfüzyonunu önleyerek vasküler oklüzyon tekniklerine olan ihtiyacı azaltmayı amaçlamalıdır. Karaciğer rezeksiyonu sırasında SVB'nin dikkatli bir şekilde kontrol edilmesiyle hepatik venöz konjesyonun azaltılması, uzun süre intraoperatif kan kaybında azalma ile ilişkilendirilmiştir. ${ }^{11-13}$ Yapılan bir çalışmada $5 \mathrm{~cm} \mathrm{H}_{2} \mathrm{O}$ veya daha düşük bir SVB'de, $5 \mathrm{~cm} \mathrm{H}_{2} \mathrm{O}^{\prime}$ dan yüksek $\mathrm{SVB}$ 'si olan hastalarla karşılaştırıldığında, kan kaybı ve transfüzyon miktarının anlamlı derecede azaldığı bulunmuştur. ${ }^{14}$

\section{Abdominal Cerrahide Sıvı Tedavisi}

Abdominal cerrahide liberal veya restriktif s1v1 protokolleri yerine, hedefe yönelik sıvı tedavisi (HYST) önerilmektedir, ${ }^{15}$ çünkü hipovolemi akut böbrek yetmezliğine, hipotansiyona ve aritmiye, hipervolemi ise pulmoner ödeme, postoperatif pnömoniye, uzamış mekanik ventilasyona, gecikmiş yara iyileşmesine, GİS'te ödem ve GİS motilitesinde azalmaya neden olabilir. ${ }^{16}$ Normovolemiyi koruyarak sıfira yakın bir balansla doku perfüzyonu sağlanmalıdır. ${ }^{15}$ Sıv1 tedavisi uygulamadan önce, S1vi replasmanına yanıtın değerlendirilmesi önerilir. AHD, NBD ve SBD, pozitif basınçlı mekanik ventilasyon altındaki hastada sıvı yanıtlılığını değerlendirmede kullanılan minimal invazif dinamik parametreler arasındadır. ${ }^{17}$ Çoğu HYST protokolünde atım hacmi (AH) maksimizasyonu (yaklaşık 3 $\mathrm{mL} / \mathrm{kg}^{\prime} l \mathrm{k}$ boluslar ile AHD'nin \%13'ün altında tutulmasi) sağlanarak, AH'de ya da kardiyak indekste \%10-15'lik bir artış, yanıt verme eşiği olarak belirlenir ${ }^{14}$. CVP değişiklikleri gibi statik parametreler sıvı yanıtını belirlemede sensitif ve spesifik değildir. ${ }^{18}$ Düşük riskli hastalarda noninvazif bir yöntem olan pletismografik değişkenlik indeksi (PDİ) takibi ile de HYST uygulanabilir. ${ }^{19}$ Siv1 yanıtının değerlendirilmesi ile hipotansiyonun diğer nedenleri (kardiyojenik, nörojenik, distribütif ve obstrüktif gibi) ayırt edilebilir. Dengeli elektrolit solüsyonları, klorür açısından zengin izotonik sıvıların (serum Fizyolojik gibi) zararlı etkilerini önleyebilir. ${ }^{15}$ Sıvı tedavisi her hasta için bireyselleştirilmelidir. ${ }^{20}$

Kan transfüzyonu diğer bir önemli konudur. Sadece hemoglobin değerine bakılarak transfüzyon tedavisi başlanmaz. Hastada fizyolojik ve klinik bulgular ve gereksinimler değerlendirilerek transfüzyon kararı alınır. Transfüzyona başlamak için 
kullanılabilecek bir "kritik hemoglobin" değeri yoktur. Bu değer ile ilgili bilimsel bir kesinlik yoktur. Bu değer, birçok etken ile değişebilir. ${ }^{21}$ Kesin olmamakla birlikte allojenik transfüzyonün, immün sistemi baskılamak suretiyle abdominal malign tümörlerde nüks oranını arttırdığı bildirilmiştir. ${ }^{22,23}$

\section{Abdominal Cerrahide Postoperatif Analjezi}

Abdominal cerrahide postoperatif analjezi hem karın ön duvarından gelen somatik, hem de periton ve visseral komponentlerden kaynaklanan sempatik blokaj1 içermelidir. Karın duvarı T7-12 ve L1 düzeyinden gelen sinir lifleri ile inerve olur.

\section{Santral Bloklar}

1. TEA, açık cerrahi için temel tekniktir. Üst abdominal (kolesistektomi, özefajektomi, gastrektomi, hepatektomi ve Whipple) için kateter yerleşim yeri T6-8 hizasından ve T4-6 düzeyinde duyu bloku oluşturacak şekilde, alt abdominal için ise T8-11 hizasından ve T2-4 düzeyinde duyu bloku oluşturacak şekilde uygulanmalıdır. TEA sadece analjezi sağlamaz; T5'ten L1'e kadar uzanan sempatik liflerin blokajıyla PS aktivite artar ve ileus önlenir. İleusun önlenmesi için kateterin T12'nin üzerinde yerleştirilmesi gerekmektedir. TEA hem sempatik blokajla hem de opioid tüketimini azaltmak suretiyle postoperatif ileusu önler. T4-S5 arası bir epidural blok, alt batın bölgesindeki girişimlerde glükoz ve kortizol seviyesindeki artışı engeller. Üst batın bölgesindeki girişimlerde ise $\mathrm{C} 6$ seviyesine çıkan bloklar bile stres yanıtını önemli derecede azaltmakla beraber tam olarak önleyememektedir. Bundan vagal sinir, frenik afferent yolun ve sempatik liflerin yetersiz blokajı, diyaframın ve peritondaki serbest sinir uçlarının uyarılması sorumlu olabilir. Laparoskopik cerrahide TEA açık cerrahide olduğu kadar üstünlük sağlamayabilir. TEA, hastada preoperatif solunum problemleri varlığında veya açık cerrahiye dönme beklentisinin olduğu durumlarda düşünülmelidir.

2. Etki süresinin sınırlı olması nedeniyle intratekal blokun major abdominal cerrahide kullanımı kısıtlıdır. ${ }^{24}$ Alt batın cerrahisinde (açık veya laparoskopik) tercih edilebilir. Akut hemodinamik etkiler yönünden özellikle hipovolemik hastalarda dikkatli olunmalıdır. ${ }^{25,26}$

\section{Periferik bloklar}

\section{Gövde Blokları}

Spinal sinirler paravertebral alandan çıktıktan sonra transversus abdominis, internal ve eksternal abdominal, rektus abdominis ile internal ve eksternal oblik kaslar arasında ilerleyerek inguinal bölgeye ulaşırlar. Bu seyir esnasında yüzeye yakın yerlerde bloke edilirler. ${ }^{24}$

\section{a) Üst Gövde Blokları}

- $\quad$ Paravertebral blok (özofajektomide TPVB)

- Erektör spina bloğu (ESB) (üst ve alt batın)

b) Alt Gövde Blokları

- Transversus abdominis plan (TAP) (üst ve alt batın)

- Oblik subkostal yaklaşım (OSTAP) (Üst batin)

- İlyoinguinal/ilyohipogastrik blok (inguinal herni)

- Rektus kılıfı bloğu (mediyan insizyon)
- Kuadratus lumborum bloğu (alt batın) ${ }^{27,28}$

- İnsizyon yerine lokal anestezik (LA) infiltrasyonu ve infüzyonu, intraperitoneal LA infüzyonu ve intravenöz lidokain infüzyonu diğer analjezi yöntemleri arasındadır; ancak tek başlarına yeterli değildir, visseral ağrının tedavisinde opioid ilavesi gerekir. $^{24}$

\section{Sistemik Analjezikler}

Opioid tüketimini ve doza bağımlı yan etkilerini azaltmak

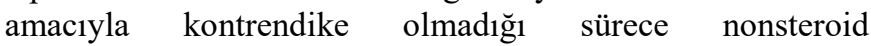
antienflamatuvarlar ve parasetamol multimodal analjezinin bir komponenti olarak mutlaka eklenmelidir. Diklofenak anastomoz kaçağı yönünden risklidir. Analjezik teknikler sadece optimal ağrı kontrolü sağlamayı değil, aynı zamanda oral alım toleransı ve erken mobilizasyonu da kolaylaştırmalıdır. Postoperatif ağrı yönetimi cerrahiye özgü olmalıdır. ${ }^{24}$

\section{Majör Abdominal Cerrahide "Enhanced Recovery After Surgery" (Cerrahi Sonrası Hızlandırılmış Iyileşme)}

ERAS ("enhanced recovery after surgery") (cerrahi sonras1 hızlandırılmış iyileşme), postoperatif sonuçları iyileştirmek için mültimodal perioperatif müdahaleler konseptini tanımlamak amacıyla kullanılan bir terimdir. On beş yıl kadar önce gündeme gelmiştir. Günümüzde özellikle majör cerrahide morbiditeyi düşürüp, hastanede kalma süresini azalttığına dair pek çok yazı mevcuttur. ERAS ameliyat öncesi dönemden başlayıp evde sonuçlanan yolculuğun tamamında bir takım değişiklikleri içerir. Esas felsefesi cerrahi travmaya bağlı metabolik stresi azaltarak en kısa zamanda normal aktiviteye dönmeyi sağlamaktır. Yirmiden fazla kanıta dayalı eleman içerir. ${ }^{29}$

ERAS protokolü preoperatif hasta görüşmesi ve hasta danışmanlığıyla başlar. Preoperatif açlık cerrahiden iki saat öncesine kadar berrak sıvıların ve altı saat öncesine kadar katı gıdaların alınması olarak önerilmektedir. Uzun süreli açlığın önlenmesi aynı zamanda intraoperatif sıvı alımını da azaltacaktır. Mekanik bağırsak temizliğinden kaçınılmalıdır. Kontrendikasyon olmadıkça preoperatif iki-üç saat öncesine kadar yapılabilen karbonhidrat yüklemesi, hastayı insülin direncinden ve katabolik süreçten korur. Antibiyotik ve derin ven trombozu profilaksisi önemsenmektedir. Uzun etkili ilaçlarla premedikasyondan kaçınılmalıdır. Kısa etkili anestezik ajan ve kas gevşeticiler kullanılmalı, anestezi süresince de TEA kullanılmalıdır; bunun için de uyanık midtorakal epidural kateter yerleştirilmelidir. Aşırı sıvı ve tuz yükünden kaçınılmalı, mümkün olduğunca az dren yerleştirilmeli, normotermi sağlanmalıdır. Postoperatif dönemde TEA ve sistemik analjezikler, bağırsak motilitesinin uyarılması mümkün olan en kısa sürede nazogastrik sonda, idrar kateterleri ve drenlerin çıkarılması, erken beslenme, erken mobilizasyon, bulantı kusmanın önlenmesi ile sıvı ve tuz alımının kısıtlanması önerilmektedir. ${ }^{30}$

Sonuç olarak, minör elektif cerrahiden majör acil cerrahiye kadar geniş bir hasta popülasyonunu içeren abdominal cerrahide anestezist çok iyi bir preoperatif değerlendirme yaparak anestezi planını ve postoperatif süreci belirlemelidir. Abdominal cerrahide önerilen tek bir anestezi tekniği olmamakla birlikte genellikle önerilen TEA+GA kombinasyonudur. Sıv1 ve kan ürünü replasmanı bireyselleştirilmiş olmalı, gereksiz kan ve sıvı transfüzyonlarından kaçınarak normovolemi sağlanmalıdır. Postoperatif analjezi işleme yönelik olmalı, hem istirahat hem de hareket halinde analjezi sağlayacak mültimodal analjezi protokolleri uygulanmalidir. 


\section{Kaynaklar}

1. Alagol A. Anesthetic Management of Abdominal Surgery. InTechOpen; 2012:5568. doi: $10.5772 / 49940$

https://www.intechopen.com/books/abdominal-surgery/anesthetic-management-of -abdominal-surgery. 05.07.2018'de erișildi.

2. Boden I, Skinner EH, Browning L, et al. Preoperative physiotherapy for the prevention of respiratory complications after upper abdominalsurgery: pragmatic, double blinded, multicentre randomised controlled trial. BMJ. 2018;360:j5916. doi:10.1136/bmj.j5916.

3. Türk Anesteziyoloji ve Reanimasyon Derneği Ansetezi Uygulama Klavuzu Preoperatif Değerlendirme.

https://www.tard.org.tr/assets/kilavuz/preoperatifdegerlendirme.pdf. 2015 tarihinde basıld1. 16.08.2018'de erișildi.

4. Lopez-Delgado JC, Ballus J, Esteve F, et al. Outcomes of abdominal surgery in patients with liver cirrhosis. World J Gastroenterol. 2016;22(9):2657-2667. doi:10.3748/wjg.v22.i9.2657.

5. Guyton AC, Hall JE. Tlbbi Fizyoloji. Nobel Tip Kitabevi; 2013:753-762.

6. Harper B, Chandler B. Splanchnic circulation. BJA Education. 2016;16(2):66-71. doi:10.1093/bjaceaccp/mkv017.

7. Freise H, Van Aken HK. Risks and benefits of thoracic epidural anaesthesia. $\mathrm{Br} \mathrm{J}$ Anaesth. 2011;107(6):859-868. doi:10.1093/bja/aer339.

8. Levine WC, Allain RM, Alston TA, Dunn PF, Kwo J, Rosow CE. Clinical Anesthesia Procedures of the Massachusetts General Hospital. $5^{\text {th }}$ ed. Lippincott Williams \& Wilkins; 1997.

9. Ogunnaike BO, Whitten CW. Gastrointestinal Disorders. In: Barash PG, Kullen BF, Stoelting RK, Cahalan MK, M. Stock MC, editors. Clinical Anesthesia. $6^{\text {th }} \mathrm{ed}$. Philadelphia: Wolters Kluwer/Lippincott Williams \& Wilkins; 2009:1222-1229.

10. Carney A, Dickinson M. Anesthesia for esophagectomy. Anesthesiol Clin. 2015;33(1):143-163. doi:10.1016/j.anclin.2014.11.009.

11. Brandes J. Part Two, Procedures. In: Pardo M and Sonner JM, editors. Manual of Anesthesia Practice. Cambridge University Press; 2007:545-547.

12. Nagelhout J, Plaus K. Handbook of Anesthesia. $5^{\text {th }}$ ed. Elsevier Inc; 2014:266 290.

13. Snowden C, Prentis J. Anesthesia for hepatobiliary surgery. Anesthesiol Clin 2015;33(1)125-141. doi:10.1016/j.anclin.2014.11.008.

14. Gurusamy KS, Li J, Sharma D, Davidson BR. Cardiopulmonary interventions to decrease blood loss and blood transfusion requirements for liver resection. Cochrane Database Syst Rev. 2009;(4):CD007338. doi:10.1002/14651858.

15. Raghunathan K, Singh M, Lobo DN. Fluid management in abdominal surgery: what, when, and when not to administer. Anesthesiol Clin. 2015;33(1):51-64. doi:10.1016/j. anclin.2014.11.004

16. Voldby AW, Brandstrup B. Fluid therapy in the perioperative setting-a clinical review. J Intensive Care. 2016;4:27. doi:10.1186/s40560-016-0154-3.
17. Marik PE, Cavallazzi R, Vasu T, Hirani A. Dynamic changes in arterial waveform derived variables and fluid responsiveness in mechanically ventilated patients: a systematic review of the literature. Crit Care Med. 2009;37(9):2642-2647. doi:10.1097/CCM.0b013e3181a590da.

18. Marik PE and Cavallazzi R. Does the central venous pressure predict fluid responsiveness? An updated meta-analysis and a plea for some common sense. Crit Care Med. 2013;41(7):1774-1781. doi:10.1097/CCM.0b013e31828a25fd.

19. Cesur S, Cardaközü T, Kus A, Türkyılmaz N, Yavuz Ö. Comparison of conventional fluid management with PVI-based goal-directed fluid management in elective colorectal surgery. J Clin Monit Comput. 2018. doi:10.1007/s10877018-0163-y.

20. Aykaç ZZ, Arslantaş MK. Sıvı tedavisi ve yönetimi (II) Monitorizasyon ve sıvı yanıtlılığının öngörülmesi. GKDA Derg. 2018;24(1):1-10. doi:10.5222/GKDAD.2018.001.

21. Türk Anesteziyoloji ve Reanimasyon Derneği Kan ve Kan Ürünleri Transfüzyonu Uygulama Klavuzu. https://www.tard.org.tr/assets/kilavuz/6.pdf. Mart 2006 tarihinde basıldı. 16.08.2018'de erișildi.

22. Wu HL, Tai YH, Lin SP, Chan MY, Chen HH, Chang KY. The impact of blood transfusion on recurrence and mortality following colorectal cancer resection: A propensity score analysis of 4,030 patients. Sci Rep. 2018;8(1):13345 doi:10.1038/s41598-018-31662-5.

23. Ejaz A, Spolverato G, Kim Y, et al. Impact of blood transfusions and transfusion practices on long-term outcome following hepatopancreaticobiliary surgery. $J$ Gastrointest Surg. 2015;19(5):887-896. doi:10.1007/s11605-015-2776-5.

24. Fawcett WJ, Baldini G. Optimal analgesia during major open and laparoscopic abdominal surgery. Anesthesiol Clin. 2015;33(1):65-78. doi:10.1016/j.anclin.2014.11.005

25. Kaur D, Khan AL, Pathak A. A comparative study of three vasopressors for maintenance of blood pressure during spinal anesthesia in lower abdominal surgeries. Anesth Essays Res. 2018;12(2):333-337. doi:10.4103/aer.AER_199_17.

26. Baloyiannis I, Perivoliotis K, Sarakatsianou C, Tzovaras G. Laparoscopic total extraperitoneal hernia repair under regional anesthesia: a systematic review of the literature. Surg Endosc. 2018;32(5):2184-2192. doi:10.1007/s00464-018-6083-6.

27. Marc Beaussier M. Innervation of the Abdominal Wall and Viscera. In: Arthur Atchabahian A and Ruchir Gupta R, Eds. The Anesthesia Guide. China: McGrawHill Medical; 2003.

28. The European Society of Regional Anaesthesia \& Pain Therapy https://esraworkshops.com/Documents/Kessler-Innsbruck\%202018abdominal\%20 wall $\% 20$ blocks.pdf. Erişim tarihi:6.08.2018

29. ERAS guidelines. http://erassociety.org/guidelines/list-of-guidelines. 16.08.2018'de erişildi.

30. Scott MJ, Miller TE. Pathophysiology of major surgery and the role of enhanced recovery pathways and the anesthesiologist to improve outcomes. Anesthesiol Clin. 2015;33(1):79-91. doi:10.1016/j.anclin.2014.11.006. 